\title{
KAJIAN KUAT DESAK BETON MUTU TINGGI DENGAN BAHAN TAMBAH METAKAOLIN MENGGUNAKAN ANALISIS MIKROSTRUKTUR
}

\author{
Wibowo ${ }^{1)}$, Antonius Mediyanto ${ }^{2)}$, Rizki Syahrani Putri ${ }^{3)}$ \\ 1) 2) Pengajar Prodi Teknik Sipil, Fakultas Teknik, Universitas Sebelas Maret \\ ,3) Mahasiswa Prodi Teknik Sipil, Fakultas Teknik, Universitas Sebelas Maret \\ J1. Ir. Sutami 36A, Kentingan Surakarta 57126; Telp 0271-634524. Email: rizkisyahrani@gmail.com
}

\begin{abstract}
The increasing of development has made new innovations in concrete to improve its quality. This innovation can be applied in the form of design methods or innovations in the material to be used. High strength concrete is concrete which has a strength above 41.4 Mpa (SNI 03-6468-2000). Concrete with high compressive strength requires more binders. Addition of metakaolin additive to concrete mixtures can improve the quality of binders in concrete. Metakaolin comes from clay which is burned at a temperature of 500-900 o c, and has gone through a calcination process. Metakaolin can increase the density of mi-crostructure arrangement in concrete so that the porosity level becomes low. This study examines the value of compressive strength of high strength concrete with $12.5 \%$ metakaolin additive through microstructure analysis using surface area analysis (SAA). Testing of compressive strength was carried out at the concrete age of 7,14,21 and 28 days using Universal Testing Ma-chine (UTM). Cylinder specimens with a diameter of $75 \mathrm{~mm}$ and a height of $150 \mathrm{~mm}$. Based on the results of the test, the strong pressure of concrete with metakaolin additive has increased by $16.27 \%$ than concrete without additives. This is followed by the pore volume value which continues to decrease in line with the increase in the age of the concrete with a per-centage decrease of $3.44 \%$ at the age of 7 days; $3.57 \%$ at the age of 14 days; $8.33 \%$ at 21 days and $13.63 \%$ at 28 days.
\end{abstract}

Keywords: high strength concrete, metakaolin, microstructure, compressive strength, surface area analysis.

\begin{abstract}
Abstrak
Pembangunan yang semakin meningkat menjadikan inovasi baru pada beton untuk meningkatkan kualitas dan mutu beton. Inovasi ini dapat diterapkan dalam bentuk metode perancangan maupun inovasi pada material yang digunakan. Beton mutu tinggi adalah beton yang mempunyai kekuatan diatas 41,4 MPa (SNI 03-6468-2000). Beton dengan kuat desak yang tinggi memerlukan lebih banyak pengikat (binder) di dalamnya. Penambahan metakaolin pada campuran beton dapat meningkatkan kualitas pengikat (binder) pada beton. Metakaolin berasal dari tanah liat yang dibakar pada suhu $500-900{ }^{\circ} \mathrm{c}$, dan telah melalui proses kalsinasi. Metakaolin mampu meningkatkan kerapatan susunan mikrostruktur pada beton dehingga tingkat porositas menjadi rendah. Penelitian ini mengkaji nilai kuat desak beton mutu tinggi dengan penambahan metakaolin $12,5 \%$ melalui analisis mikrostruktur dengan metode surface area analysis (SAA). Pengujian kuat tekan dilakukan pada umur beton 7,14,21, dan 28 hari menggunakan alat Universal Testing Machine (UTM). Benda uji berbentuk silinder dengan diameter $75 \mathrm{~mm}$ dan tinggi $150 \mathrm{~mm}$. Berdasarkan hasil pengujian nilai kuat desak beton dengan bahan tambah metakaolin mengalami peningkatan sebesar $16,27 \%$ terhadap beton tanpa bahan tambah. Hal ini diikuti dengan nilai volume pori yang terus menurun sejalan dengan bertambah nya umur beton dengan persentase penurunan 3,44 \% pada umur 7 hari; 3,57\% pada umur 14 hari; $8,33 \%$ pada umur 21 hari dan 13,63\% pada umur 28 hari.
\end{abstract}

Kata Kunci : beton mutu tinggi, metakaolin, mikrostruktur, kuat desak, surface area analysis.

\section{PENDAHULUAN}

Berbagai konstruksi bangunan didirikan untuk memenuhi kebutuhan masyarakat yang semakin lama semakin meningkat. Pengunaan beton merupakan salah satu material yang banyak digunakan dalam konstruksi bangunan. Dibutuhkan inovasi dan pembaruan sebagai pendukung untuk memenuhi kualitas dan mutu beton. Kekuatan beton merupakan salah satu parameter penentu mutu beton. Semakin tinggi nilai kekuatan pada beton berpengaruh pada kekuatan,kekakuan dan daktilitas konstruksi bangunan.

Beton dengan kuat desak yang tinggi memerlukan bahan pengikat (binder) yang lebih banyak. Penggunaan bahan tambah metakaolin pada beton dimaksudkan mengurangi penggunaan semen pada campuran beton dan untuk meningkatkan kualitas bahan pengikat pada beton. Penambahan metakaolin meningkatkan kerapatan susunan mikrostruktur pada beton. Campuran air dan semen akan menghasilkan senyawa calsium silikat hidrat (C-S-H) untuk membentuk kekuatan,kekerasan dan keawetan pada beton. Selain itu, reaksi ini juga menghasilkan $\mathrm{Ca}(\mathrm{OH})_{2}$ yang akan dengan mudah bereaksi dengan asam sulfat dan akan melemahkan beton. Penambahan metakaolin yang memiliki kandungan silika akan memperkuat ikatan dalam beton. 
Pada umumnya beton dengan kuat desak yang tinggi memiliki nilai faktor air semen yang rendah, dengan penambahan metakaolin pasta semen menjadi lebih homogen dan meningkatkan kerapatan mortar,namun dapat menurunkan tingkat workability pada beton. Superplasticizer digunakan untuk meningkatkan workability pada beton dengan nilai faktor air semen (FAS) yang rendah.

Penelitian ini membandingkan nilai kuat desak berdasarkan susunan mikrostruktur beton dengan bahan tambah metakaolin terhadap beton tanpa bahan tambah. Pengujian kuat desak dilakukan dengan Universal Testing Macbine (UTM) dan untuk mengetahui susunan mikrostruktur pada beton dilakukan pengujian dengan metode surface area analysis (SAA) untuk mengetahui nilai volume pori dan luas permukaan pori pada beton. Tingkat porositas berpengaruh terhadap kekuatan beton,semakin rendah tingkat porositas menjadikan distribusi pembebanan yang merata pada beton. Tujuan dari penelitian ini adalah untuk mengkaji nilai kuat desak beton dengan bahan tambah metakaolin kadar 12,5\% melalui analisis mikrostruktur pada umur beton 7,14,21 dan 28 hari.

Beton merupakan campuran semen portland atau semen hidrolis lainnya, agregat halus, agregat kasar, dan air, dengan atau tanpa bahan tambah (admixture atau additive) (SNI 2847-2013). Beton merupakan bahan yang bersifat getas. Kuat tarik yang dimiliki beton hanya berkisar 9\%-15\% dari kuat tekan beton (Dipohusodo,1999). Beton mutu tinggi (high strength concrete) tercantum dalam (SNI 03-6468-2000) adalah beton yang memiliki kuat desak yang disyaratkan lebih dari $41,4 \mathrm{MPa}$.

Metakaolin merupakan pozzolan yang dibuat dari kalsinasi kaolin. Berdasarkan (SNI-2847-2013) yang merujuk pada ASTM C-618 metakaolin termasuk dalam pozzolan kelas N. Bahan ini adalah pozzolan yang sangat efisien dan bereaksi cepat dengan kalsium hidrat hasil dari hidrasi semen melalui reaksi pozzolan sehingga menghasilkan kalsium silikat hidrat dan kalsium alumina silikat hidrat (Srivastava,2012). Penggunaan metakaolin pada campuran beton dapat berfungsi sebagai pengisi pori karena ukurannya yang kecil,selain itu juga dapat membuat pasta semen menjadi lebih homogen. Tingkat homogenitas beton yang semakin tinggi menurunkan porositas pada beton karena reaksi antara metakaolin dengan kalsium silikat hidrat hasil reaksi hidrasi semen.

Hidrasi adalah bereaksinya unsur yang terkandung dalam semen dengan air. Tingkat kecepatan hidrasi pada semen tergantung pada kandungan senyawa didalam nya. Senyawa yang terdapat pada semen antara lain alit $\left(\mathrm{C}_{3} \mathrm{~S}\right)$, belit $\left(\mathrm{C}_{2} \mathrm{~S}\right)$, ferit $\left.\mathrm{C}_{4} \mathrm{AF}\right)$ dan aluminat $\mathrm{C}_{3} \mathrm{~A}$. Produk utama hidrasi semen adalah $\mathrm{CSH}$ atau kalsium silikat hidrat yang dihasilkan dari reaksi Alit $\left(\mathrm{C}_{3} \mathrm{~S}\right)$ dan Belit $\left(\mathrm{C}_{2} \mathrm{~S}\right)$ dengan air (Kurtis,2013). Pada saat semen bercampur dengan air ,semen menumbuhkan konsentrasi saturasi senyawa yang mengendap sebagai padatan. Alit $\left(\mathrm{C}_{3} \mathrm{~S}\right)$,belit $\left(\mathrm{C}_{2} \mathrm{~S}\right)$, ferit $\mathrm{C}_{4} \mathrm{AF}$ ) dan aluminat $\mathrm{C}_{3} \mathrm{~A}$ bereaksi dengan air dan menghasilkan efek yang berbeda pada susunan mikrostruktur beton. Susunan mikrostrutur dari produk reaksi hidrasi berpengaruh pada nilai kuat desak beton.

Bahan pengikat (binder) berperan untuk meningkatkan kualitas beton yang bergantung pada tingkat keterikatan antara agregat agar menjadi satu kesatuan. Sifat komposit beton bergantung pada Interfacial Transition Zone (ITZ) . Interfacial Transition Zone (ITZ) merupakan suatu daerah peralihan disekitar pasta dengan agergat. Kandungan CSH dan unbydrated particles tergolong rendah, namun kandungan $\mathrm{Ca}(\mathrm{OH})_{2}$ cukup tinggi sehingga memicu lebih banyak pori pada ITZ. Pada saat terjadi pembebanan, microcrack beresiko muncul pada area ITZ, karena pada daerah ITZ memiliki porositas yang tinggi (Paramita,2008)

Kuat desak beton adalah kemampuan beton terhadap beban yang dapat dihitung dengan besarnya beban per satuan luas. Kualitas beton yang tinggi dapat dilihat dari kuat desaknya, bila semakin tinggi kuat desak yang dihasilkan, maka semakin tinggi pula kualitas beton tersebut (Mulyono, 2004). Penggunaan faktor air semen yang semakin rendah meningkatkan kuat desak pada beton (Lathifah,2018). Nilai konversi kuat desak digunakan untuk memprediksi kuat desak pada beton.

Nilai konversi kuat desak beton menurut PBI 1971 dapat dilihat pada Tabel 1.

Tabel 1. Hubungan antara Umur dan Nilai Kuat Desak Beton

\begin{tabular}{cccccccc}
\hline Umur (Hari) & $\mathbf{3}$ & $\mathbf{7}$ & $\mathbf{1 4}$ & $\mathbf{2 1}$ & $\mathbf{2 8}$ & $\mathbf{9 0}$ & $\mathbf{3 6 5}$ \\
\hline $\begin{array}{c}\text { Semen Portlant } \\
\text { Tipe 1 }\end{array}$ & 0.46 & 0.70 & 0.88 & 0.96 & 1.0 & - & - \\
\hline $\begin{array}{c}\text { Semen Portland } \\
\text { Biasa }\end{array}$ & 0.40 & 0.65 & 0.88 & 0.95 & 1.0 & 1.2 & 1.35 \\
\hline
\end{tabular}




\begin{tabular}{llllllll}
\hline $\begin{array}{c}\text { Semen Portland } \\
\text { dengan Kuat } \\
\text { Awal Tinggi }\end{array}$ & 0.55 & 0.75 & 0.90 & 0.95 & 1.0 & 1.15 & 1.2 \\
\hline Analisis perhitungan kuat desak beton merujuk pada SNI & 1974-2011 tentang Cara Uji Kuat Tekan Beton dengan
\end{tabular}

Benda Uji Silinder dapat dilihat pada Persamaan [1].

$f^{\prime} c=\frac{P}{A}$

dengan:

$f^{\prime} c=$ Tegangan desak beton $(\mathrm{MPa})$

$\mathrm{P} \quad=$ Gaya desak $(\mathrm{N})$

A $=$ Luas penampang benda uji $\left(\mathrm{mm}^{2}\right)$

Pengujian mikrostruktur pada beton diuji melalui metode surface area analisis (SAA). Pengujian ini bertujuan untuk mengetahui nilai luas permukaan dan volume pori pada beton. Tingkat porositas pada beton berkaitan dengan nilai kekuatan beton

\section{METODE}

Metode yang digunakan dalam penelitian adalah metode eksperimental,dengan memperhatikan nilai kuat desak rencana diatas 41,4 MPa dan penggunaan metakaolin sebesar 12,5\%. Penggunaan kadar metakaolin 12,5\% berdasarkan hasil penelitian Dharmawan, 2017 yang menyebutkan bahwa variasi penggunaan bahan tambah metakaolin tersebut merupakan kadar maksimum untuk mencapai nilai kuat desak maksimum. Pengujian dilakukan di Laboratorium Bahan dan Struktur Teknik Sipil dan Laboratorium MIPA Universitas Sebelas Maret. Sampel yang digunakan berjumlah 24 sampel dengan ukuran diameter $75 \mathrm{~mm}$ dan tinggi $150 \mathrm{~mm}$.

Kode dan jumlah sampel yang digunakan dapat dilihat pada Tabel 2.

Tabel 2. Kode dan Jumlah Benda Uji

\begin{tabular}{|c|c|c|c|c|c|}
\hline No. & $\begin{array}{c}\text { Umur Beton } \\
\text { (Hari) }\end{array}$ & $\begin{array}{c}\text { Kode Benda Uji } \\
\text { dengan Metakaolin }\end{array}$ & $\begin{array}{l}\text { Jumlah } \\
\text { Benda Uji }\end{array}$ & $\begin{array}{c}\text { Kode Benda Uji } \\
\text { Tanpa Metakaolin }\end{array}$ & $\begin{array}{c}\text { Jumlah Benda } \\
\text { Uji }\end{array}$ \\
\hline \multirow{3}{*}{1} & \multirow{3}{*}{ (1 } & $\mathrm{B}_{\mathrm{HSC}} \mathrm{MK} 7-\mathrm{A}$ & \multirow{3}{*}{3} & $\mathrm{~B}_{\mathrm{HSC}} \mathrm{N} 7-\mathrm{A}$ & \multirow{3}{*}{ 资 } \\
\hline & & $\mathrm{B}_{\mathrm{HSC}} \mathrm{MK} 7-\mathrm{B}$ & & $\mathrm{B}_{\mathrm{HSC}} \mathrm{N} 7-\mathrm{B}$ & \\
\hline & & $\mathrm{B}_{\mathrm{HSC}} \mathrm{MK} 7-\mathrm{C}$ & & $\mathrm{B}_{\mathrm{HSC}} \mathrm{N} 7-\mathrm{C}$ & \\
\hline \multirow{3}{*}{2} & \multirow{3}{*}{14} & $\mathrm{~B}_{\mathrm{HSC}} \mathrm{MK} 14-\mathrm{A}$ & \multirow{3}{*}{3} & $\mathrm{~B}_{\mathrm{HSC}} \mathrm{N} 14-\mathrm{A}$ & \multirow{3}{*}{3} \\
\hline & & $\mathrm{B}_{\mathrm{HSC}} \mathrm{MK} 14-\mathrm{B}$ & & $\mathrm{B}_{\mathrm{HSC}} \mathrm{N} 14-\mathrm{B}$ & \\
\hline & & $\mathrm{B}_{\mathrm{HSC}} \mathrm{MK} 14-\mathrm{C}$ & & $\mathrm{B}_{\mathrm{HSC}} \mathrm{N} 14-\mathrm{C}$ & \\
\hline \multirow{3}{*}{3} & \multirow{3}{*}{21} & $\mathrm{~B}_{\mathrm{HSC}} \mathrm{MK} 21-\mathrm{A}$ & \multirow{3}{*}{3} & $\mathrm{~B}_{\mathrm{HSC}} \mathrm{N} 21-\mathrm{A}$ & \multirow{3}{*}{3} \\
\hline & & $\mathrm{B}_{\mathrm{HSC}} \mathrm{MK} 21-\mathrm{B}$ & & $\mathrm{B}_{\mathrm{HSC}} \mathrm{N} 21-\mathrm{B}$ & \\
\hline & & $\mathrm{B}_{\mathrm{HSC}} \mathrm{MK} 21-\mathrm{C}$ & & $\mathrm{B}_{\text {HSC }} \mathrm{N} 21-\mathrm{C}$ & \\
\hline \multirow{3}{*}{4} & \multirow{3}{*}{28} & $\mathrm{~B}_{\mathrm{HSC}} \mathrm{MK} 28-\mathrm{A}$ & & $\mathrm{B}_{\mathrm{HSC}} \mathrm{N} 28-\mathrm{A}$ & \multirow{3}{*}{3} \\
\hline & & $\mathrm{B}_{\mathrm{HSC}}$ MK 28-B & 3 & $\mathrm{~B}_{\mathrm{HSC}} \mathrm{N} 28-\mathrm{B}$ & \\
\hline & & $\mathrm{B}_{\mathrm{HSC}} \mathrm{MK} 28-\mathrm{C}$ & & $\mathrm{B}_{\mathrm{HSC}} \mathrm{N} 28-\mathrm{C}$ & \\
\hline \multicolumn{3}{|c|}{ Total Benda Uji MK } & 12 & Total Benda Uji N & 12 \\
\hline \multicolumn{3}{|c|}{ Jumlah Total Benda Uji } & & 24 & \\
\hline
\end{tabular}

- $\quad B_{H S C} \mathrm{MK}$ : Beton dengan bahan tambah metakaolin

- $\mathrm{B}_{\mathrm{HSC}} \mathrm{N}$ : Beton tanpa bahn tambah

Pengujian material dilakukan untuk mengetahui kualitas agregat yang digunakan. Pengujian agregat yang dilakukan pada penelitian ini antara lain pengujian kadar lumpur,kadar zat organik, spesific gravity dan gradasi pada agregat. Metakaolin yang digunakan diuji melalui XRF Test untuk mengetahui kandungan yang berada di dalam nya. Pengujian beton segar dilakukan dengan uji slump test yang bertujuan untuk mengetahui tingkat workability pada beton. Pengujian nilai kuat desak pda beton dilakukan dengan Universal Testing Machine (UTM), selanjutnya serpihan sampel beton ditumbuk dengan ukuran saringan no.50 $(0,3 \mathrm{~mm})$ dan digunakan untuk pengujian mikrostruktur beton melalui alat surface area analyzer (SAA). 


\section{HASIL DAN PEMBAHASAN}

\section{Hasil Pengujian Agregat Halus}

Agregat halus yang digunakan berasal dari pasir merapi. Rekapitulasi hasil pengujian agregat halus dapat dilihat pada Tabel 3.

Tabel 3. Rekapitulasi Hasil Pengujian Agregat Halus

\begin{tabular}{lccc}
\hline \multicolumn{1}{c}{ Jenis Pengujian } & Hasil Pengujian & Standar & Keterangan \\
\hline Bulk Spec Gravity SSD & 2,572 & $\begin{array}{c}2,5-2,7 \\
\text { (ASTM C-128) }\end{array}$ & $\begin{array}{c}\text { Memenuhi } \\
\text { syarat }\end{array}$ \\
\hline Kandungan Lumpur & $2,20 \%$ & $\begin{array}{c}<5 \% \\
(\text { PBI 1971) }\end{array}$ & $\begin{array}{c}\text { Memenuhi } \\
\text { syarat }\end{array}$ \\
\hline Kandungan Zat Organik & Kuning Muda & $\begin{array}{c}\text { Kuning Muda } \\
\text { (PBI 1971) }\end{array}$ & $\begin{array}{c}\text { Memenuhi } \\
\text { syarat }\end{array}$ \\
\hline Modulus Kehalusan & 2,59 & $\begin{array}{c}1,5-3,8 \\
(\text { SII-0052-80) }\end{array}$ & $\begin{array}{c}\text { Memenuhi } \\
\text { syarat }\end{array}$ \\
\hline
\end{tabular}

\section{Hasil Pengujian Agregat Kasar}

Agregat kasar yang digunkan berasal dari Sentolo,Kulon Progo . Rekapitulasi hasil pengujian agregat kasar dapat dilihat pada Tabel 4.

Tabel 4. Rekapitulasi Hasil Pengujian Agregat Kasar

\begin{tabular}{lccc}
\hline \multicolumn{1}{c}{ Jenis Pengujian } & Hasil Pengujian & Standar & Keterangan \\
\hline Bulk Spec Gravity SSD & 2,674 & $\begin{array}{c}2,5-2,7 \\
\text { (ASTM C-128) }\end{array}$ & $\begin{array}{c}\text { Memenuhi } \\
\text { syarat }\end{array}$ \\
\hline Abrasi & $26,47 \%$ & $\begin{array}{c}<50 \% \\
\text { (PBI 1971) }\end{array}$ & $\begin{array}{c}\text { Memenuhi } \\
\text { syarat }\end{array}$ \\
\hline Modulus Kehalusan & 7,37 & $\begin{array}{c}5-8 \\
\text { (SNI T-15-1990-03) }\end{array}$ & $\begin{array}{c}\text { Memenuhi } \\
\text { syarat }\end{array}$ \\
\hline
\end{tabular}

\section{Rancang Campuran Beton (Mix Design)}

Tabel 5. Menampilkan komposisi material yang digunakan dalam $1 \mathrm{~m}^{3}$ beton.

Tabel 5. Rancang campuran $\mathrm{B}_{\mathrm{HSC}} \mathrm{N}$ dan $\mathrm{B}_{\mathrm{HSC}} \mathrm{MK} 12,5 \%$ per $1 \mathrm{~m}^{3}$

\begin{tabular}{ccccccc}
\hline Kode & Ag. Kasar $\left(\mathbf{K g} / \mathbf{m}^{3}\right)$ & $\begin{array}{c}\text { Ag. } \\
\mathbf{H a l u s} \\
\left(\mathbf{K g} / \mathbf{m}^{3}\right)\end{array}$ & Semen $\left(\mathbf{K g} / \mathbf{m}^{3}\right)$ & $\begin{array}{c}\text { Metakaolin } \\
\left(\mathbf{K g} / \mathbf{m}^{3}\right)\end{array}$ & $\begin{array}{c}\text { Air } \\
\left(\mathbf{l t} / \mathbf{m}^{3}\right)\end{array}$ & $\begin{array}{c}\text { Admixtures } \\
\left(\mathbf{l t} / \mathbf{m}^{3}\right)\end{array}$ \\
\hline $\mathrm{B}_{\mathrm{HSC}} \mathrm{N}$ & 991,98 & 780,67 & 550 & 0 & 123,75 & 7,15 \\
\hline $\begin{array}{c}\mathrm{B}_{\mathrm{HSC}} \mathrm{MK} \\
12,5 \%\end{array}$ & 985,19 & 775,32 & 481,25 & 68,75 & 123,75 & 7,15 \\
\hline
\end{tabular}

- $\quad \mathrm{B}_{\mathrm{HSC}} \mathrm{MK}:$ Beton dengan bahan tambah metakaolin

- $\mathrm{B}_{\mathrm{HSC}} \mathrm{N}$ : Beton tanpa bahn tambah

\section{Pengujian Slump}

Hasil pengujian slump ditampilkan pada Gambar.1

Pengujian Slump

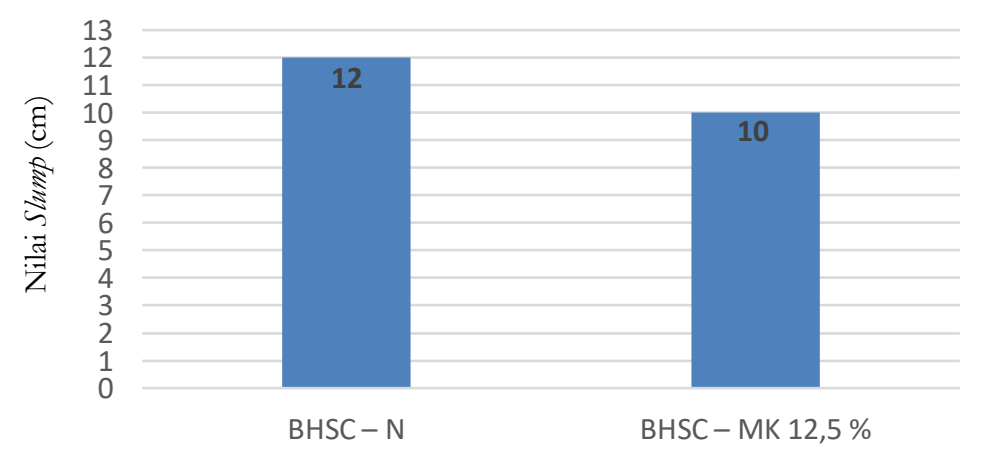


Gambar 1. Rekapitulasi Pengujian Slump Beton

Beton dengan bahn tambah metakaolin memiliki nilai slump yang lebih rendah jika dibandingkan dengan beton tanpa bahan tambah. Hal ini disebabkan karena tingkat homogenitas pada beton dengan bahan tambah metakaolin lebih tinggi dibanding beton tanpa bahan tambah,sehingga kelecakan menjadi lebih rendah.

\section{Pengujian Kuat Desak}

Rekapitulasi hasil pengujian kuat desak untuk $\mathrm{B}_{\mathrm{HSC}} \mathrm{N}$ dan $\mathrm{B}_{\mathrm{HSC}} \mathrm{MK}$ dapat dilihat pada Tabel 6.

Tabel 6. Rekapitulasi Hasil Pengujian Kuat Desak

\begin{tabular}{|c|c|c|c|}
\hline Umur & Beton & $\begin{array}{c}\text { f'c rata- } \\
\text { rata } \\
(\mathrm{MPa})\end{array}$ & $\begin{array}{c}\text { Persentase Kenaikan } \\
\text { f'c rata-rata }(\%)\end{array}$ \\
\hline \multirow{2}{*}{7 Hari } & $\mathrm{B}_{\mathrm{HSC}} \mathrm{N} 7$ & 31,75 & \multirow{2}{*}{$-6,687$} \\
\hline & $\mathrm{B}_{\mathrm{HSC}} \mathrm{MK} 7$ & 29,63 & \\
\hline \multirow{2}{*}{14 Hari } & $\mathrm{B}_{\mathrm{HSC}} \mathrm{N} 14$ & 34,64 & \multirow{2}{*}{$-1,753$} \\
\hline & $\mathrm{B}_{\mathrm{HSC}} \mathrm{MK} 14$ & 34,04 & \\
\hline \multirow{2}{*}{21 Hari } & $\mathrm{B}_{\mathrm{HSC}} \mathrm{N} 21$ & 40,49 & \multirow{2}{*}{$-2,301$} \\
\hline & $\mathrm{B}_{\mathrm{HSC}} \mathrm{MK} 21$ & 39,56 & \\
\hline \multirow{2}{*}{28 Hari } & $\mathrm{B}_{\mathrm{HSC}}$ N 28 & 42,59 & \multirow{2}{*}{16,276} \\
\hline & $\mathrm{B}_{\mathrm{HSC}} \mathrm{MK} 28$ & 49,53 & \\
\hline
\end{tabular}

- $\quad \mathrm{B}_{\mathrm{HSC}} \mathrm{MK}:$ Beton dengan bahan tambah metakaolin

- $\mathrm{B}_{\mathrm{HSC}} \mathrm{N}$ : Beton tanpa bahn tambah

Berdasarkan rekapitulasi pengujian kuat desak pada Tabel.6 dapat dilihat pengaruh penambahan metakaolin dalam berbagai umur. Pada hari ke 7,14 dan 21 beton dengan bahan tambah metakaolin belum mengalami peningkatan jika dibandingkan dengan beton tanpa bahan tambah. Hal ini disebabkan karena pada hari ke 7,14 dan 21 reaksi hidrasi belum berjalan optimal. Pada hari ke 28, peningkatan nilai kuat tekan mencapai 16,3\% jika dibandingkan dengan beton tanpa bahan tambah.

Berdasarkan sifat fisiknya metakaolin bertujuan untuk meningkatkan kekuatan beton,kepadatan dan memperkecil permeabilitas. Metakaolin sangat membantu dalam proses hidrasi semen. Berikut adalah reaksi hidrasi semen:

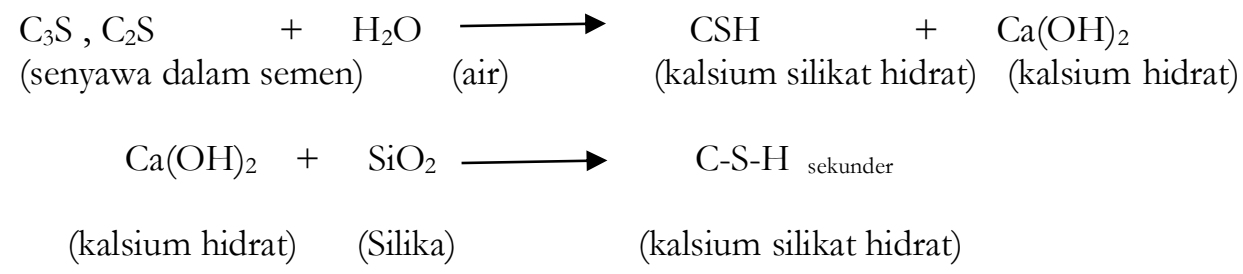

Metakaolin merupakan bahan pozzolan yang banyak mengandung $\mathrm{SiO}_{2}$ yang bereaksi dengan kalsium hidrat $\left(\mathrm{Ca}(\mathrm{OH})_{2}\right)$ hasil hidrasi semen. Pada saat reaksi pozzolanik, metakaolin mengikat senyawa $\mathrm{C}-\mathrm{H}$ dan mengubah menjadi C-S-H sekunder. Terbentuknya C-S-H dapat membantu menutupi rongga yang terbentuk dari proses hidrasi semen sehingga tingkat kepadatan menjadi meningkat dan memperkecil porositas pada beton.

Pembentukan C-S-H berperan penting sebagai pengikat agregat pada beton,sehingga dapat mengurangi microcrack pada daerah Interfacial Transition Zone (ITZ) pada saat pembebanan.

Hubungan kuat desak dengan umur beton dapat dilihat pada gambar.2 : 
Hubungan Kuat Desak dengan Umur Beton

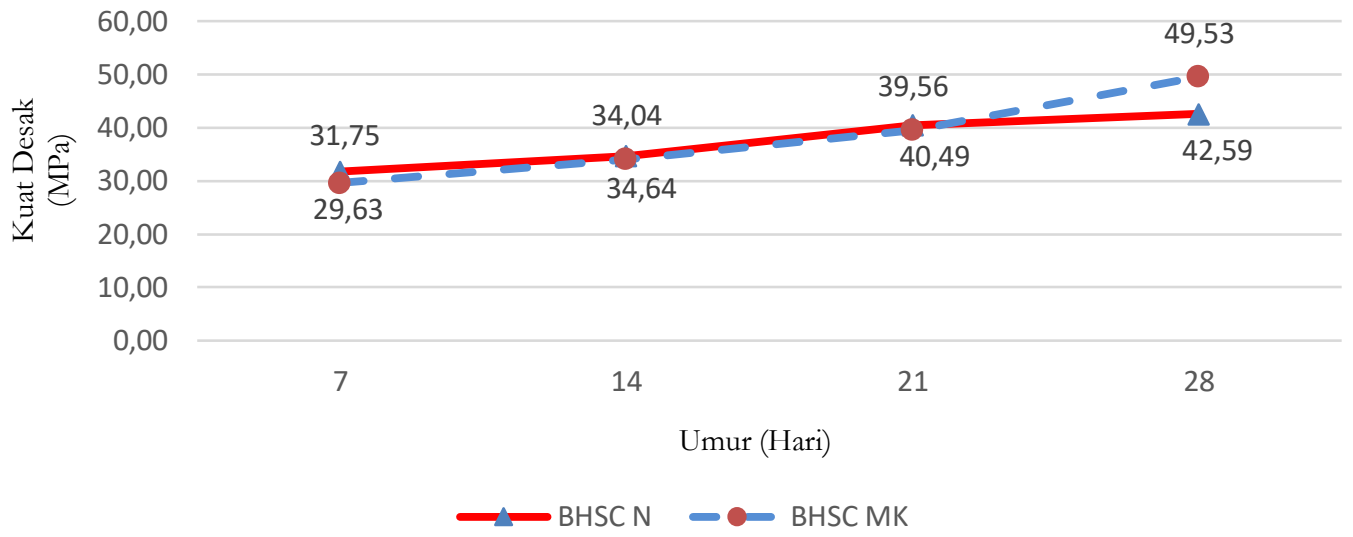

Gambar.2 Hubungan Kuat Desak dengan Umur Beton

- $\quad B_{H S C} M K$ : Beton dengan bahan tambah metakaolin

- $\mathrm{B}_{\mathrm{HSC}} \mathrm{N}$ : Beton tanpa bahan tambah

Reaksi hidrasi semen berlanjut hingga beton berumur 90 hari (Kurtis,2013). Proses hidrasi berjalan sesuai bertambahnya umur beton. Penelitian ini hanya mencakup hingga umur beton mencapai 28 hari,dengan asumsi kecepatan hidrasi telah mencapai 100\%.Kecepetan tingkat hidrasi pada semen ditampilkan pada Gambar.3 berikut :

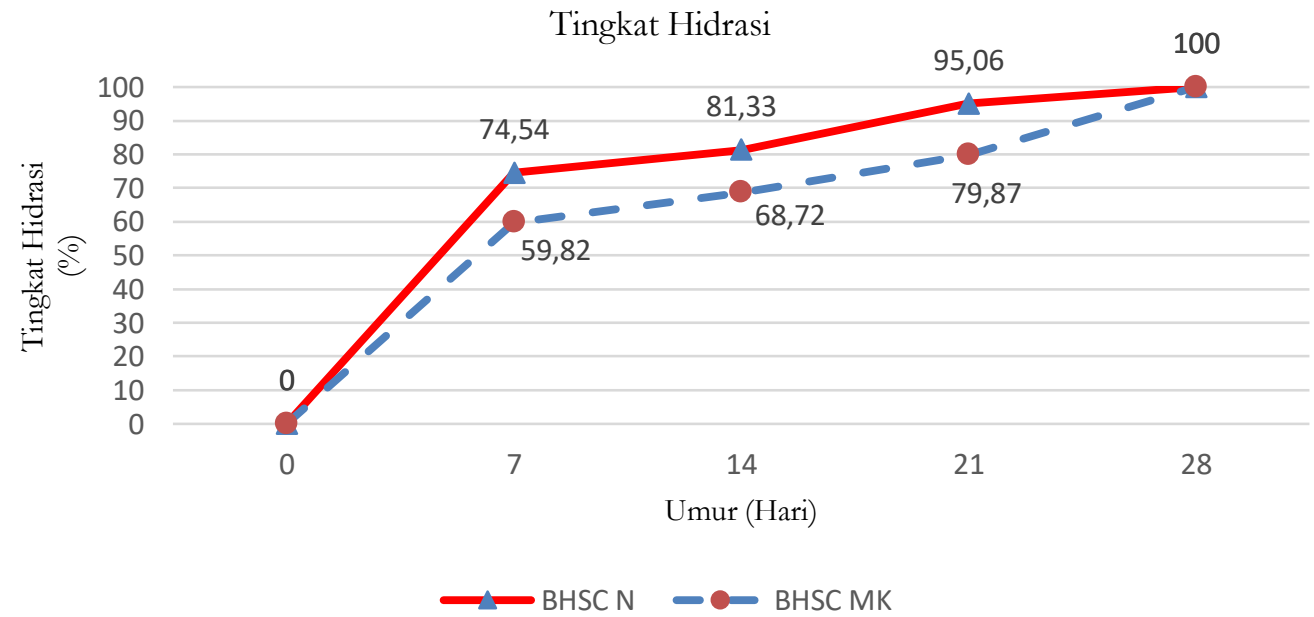

Gambar 3. Tingkat Hidrasi $\mathrm{B}_{\mathrm{HSC}} \mathrm{N}$ dan $\mathrm{B}_{\mathrm{HSC}} \mathrm{MK}$

- $\quad \mathrm{B}_{\mathrm{HSC}} \mathrm{MK}:$ Beton dengan bahan tambah metakaolin

- $\mathrm{B}_{\mathrm{HSC}} \mathrm{N}$ : Beton tanpa bahn tambah

Berdasarkan hasil pengujian kuat desak dapat diketahui nilai konversi kuat desak hasil percobaan dengan Peraturan Beton Bertulang Indonesia (PBBI,1971) yang bias dilihat pada Tabel.7

Tabel 7. Nilai Konversi Kuat Desak

\begin{tabular}{ccccc}
\hline Umur Beton & $\mathbf{7}$ & $\mathbf{1 4}$ & $\mathbf{2 1}$ & $\mathbf{2 8}$ \\
\hline PBBI 1971 & 0.6 & 0.88 & 0.95 & 1.00 \\
\hline
\end{tabular}




\begin{tabular}{lllll}
\hline Beton $\mathbf{B}_{\text {HSC }} \mathbf{N}$ & 0.75 & 0.81 & 0.95 & 1.00 \\
\hline Beton $\mathbf{B}_{\text {HSC }}$ MK & 0.60 & 0.69 & 0.80 & 1.00 \\
\hline
\end{tabular}

- $\mathrm{B}_{\mathrm{HSC}} \mathrm{MK}$ : Beton dengan bahan tambah metakaolin

- $\mathrm{B}_{\mathrm{HSC}} \mathrm{N}$ : Beton tanpa bahn tambah

\section{Pengujian Mikrostruktur Beton}

Penguijian dilakukan melalui metode Surface Area Analisis (SAA) dengan sampel beton umur 7,14,21 dan 28 hari. Rekapitulasi hasil pengujian surface area analisis untuk beton $\mathrm{B}_{\mathrm{HSC}} \mathrm{N}$ maupun $\mathrm{B}_{\mathrm{HSC}} \mathrm{MK}$ umur 7, 14, 21, dan 28 hari dapat dilihat pada Tabel 8.

Tabel 8. Rekapitulasi Hasil Pengujian Surface Area Analysis (SAA)

\begin{tabular}{|c|c|c|c|c|}
\hline Umur & Beton & $\begin{array}{c}\text { Radius Pori } \\
(\AA)\end{array}$ & $\begin{array}{l}\text { Volume Pori } \\
\text { (cc/g) }\end{array}$ & $\begin{array}{l}\text { Luas Permukaan } \\
\qquad\left(\mathrm{m}^{2} / \mathrm{g}\right)\end{array}$ \\
\hline \multirow{2}{*}{7 Hari } & $\mathrm{B}_{\mathrm{HSC}} \mathrm{N} 7$ & 18,23 & 0,029 & 22,10 \\
\hline & $\mathrm{B}_{\mathrm{HSC}} \mathrm{MK} 7$ & 18,25 & 0,028 & 20,42 \\
\hline \multirow{2}{*}{14 Hari } & $\mathrm{B}_{\mathrm{HSC}} \mathrm{N} 14$ & 18,21 & 0,028 & 20,45 \\
\hline & $\mathrm{B}_{\mathrm{HSC}} \mathrm{MK} 14$ & 18,20 & 0,027 & 19,11 \\
\hline \multirow{2}{*}{21 Hari } & $\mathrm{B}_{\mathrm{HSC}} \mathrm{N} 21$ & 18,16 & 0,024 & 15,71 \\
\hline & $\mathrm{B}_{\mathrm{HSC}} \mathrm{MK} 21$ & 18,12 & 0,022 & 14,01 \\
\hline \multirow{2}{*}{28 Hari } & $\mathrm{B}_{\mathrm{HSC}} \mathrm{N} 28$ & 18,12 & 0,022 & 11,97 \\
\hline & $\mathrm{B}_{\mathrm{HSC}} \mathrm{MK} 28$ & 18,04 & 0,019 & 11,25 \\
\hline
\end{tabular}

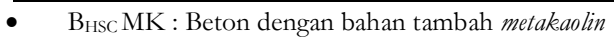

- $\quad B_{\text {HSC }} \mathrm{N}$ : Beton tanpa bahn tambah

Berdasarkan Tabel 8, hubungan antara luas pori dan volume pori berbanding lurus. Semakin kecil luas permukaan pada pori diikuti dengan makin rendahnya tingkat volume pori. Penambahan umur beton membuat luas permukaan dan tingkat volume pori menurun. Nilai luas permukaan yang didapat menyatakan luas adsorbsi material berpori yang berbentuk atom. Berikut adalah perbandingan nilai volume pori pada pasta beton dengan bahan tambah metakaolin $\mathrm{B}_{\mathrm{HSC}} \mathrm{MK}$ dan beton tanpa bahan tambah $\mathrm{B}_{\mathrm{HSC}} \mathrm{N}$.

Perbandingan Volume Pori antara Pasta Beton $\mathrm{B}_{\mathrm{HSC}} \mathrm{N}$ dan $\mathrm{B}_{\mathrm{HSC}} \mathrm{MK}$

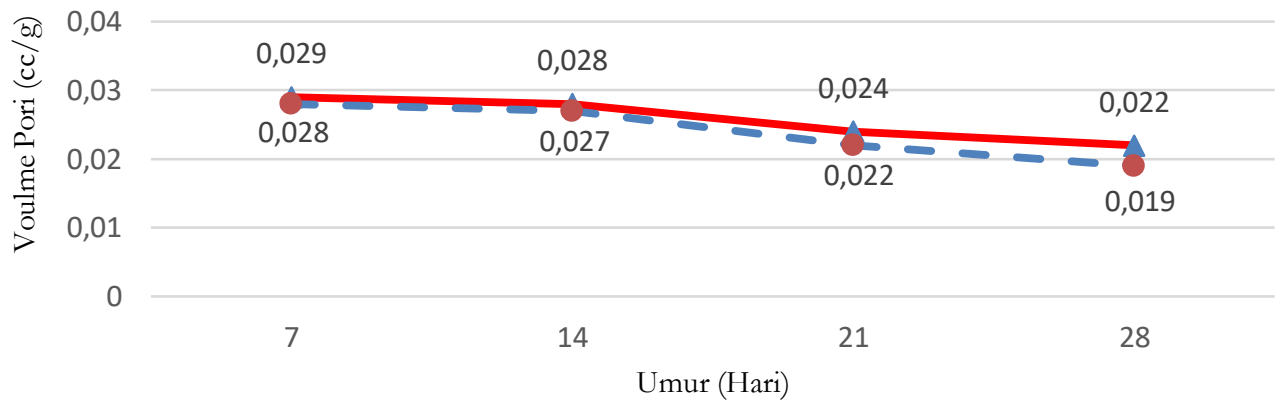

$\longrightarrow$ BHSCN $\longrightarrow$ BHSC MK

Gambar 4. Perbandingan Volume Pori antara Pasta $\mathrm{B}_{\mathrm{HSC}} \mathrm{N}$ dan $\mathrm{B}_{\mathrm{HSC}} \mathrm{MK}$

Hubungan nilai kuat desak dengan tingkat porositas beton $\mathrm{B}_{\mathrm{HSC}} \mathrm{N}$ dan $\mathrm{B}_{\mathrm{HSC}} \mathrm{MK}$ dapat dilihat pada gambar.5.

Hubungan Volume Pori Pasta dengan Kuat Desak Beton $\mathrm{B}_{\mathrm{HSC}} \mathrm{N}$ dan $\mathrm{B}_{\mathrm{HSC}} \mathrm{MK}$

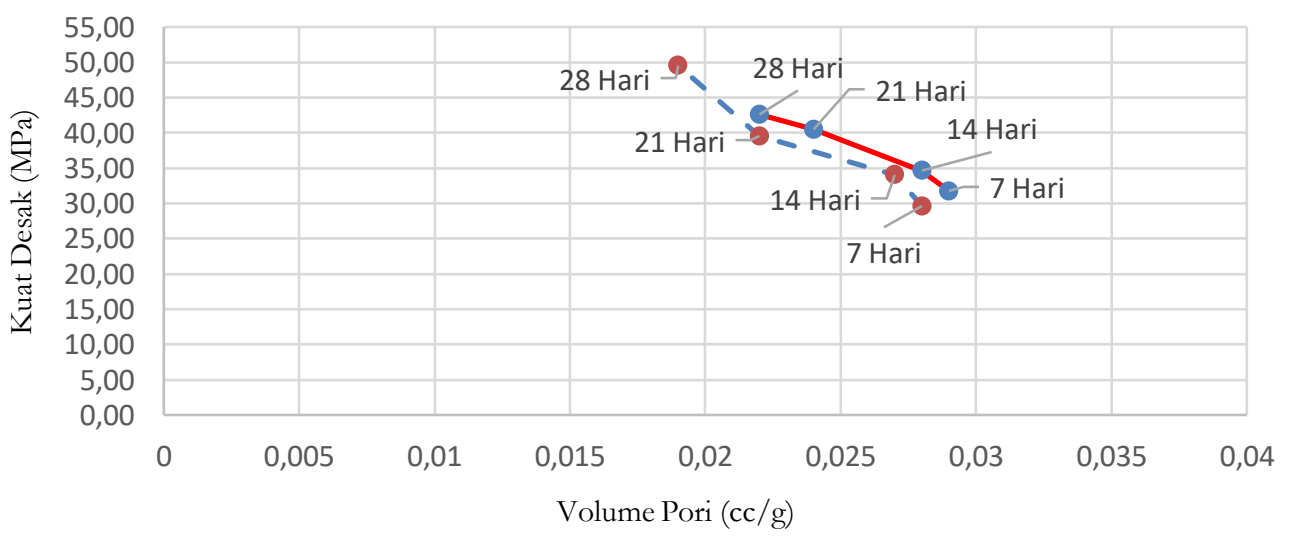


Gambar 5. Hubungan Volume pori dengan Kuat Desak

- $\quad \mathrm{B}_{\mathrm{HSC}} \mathrm{MK}$ : Beton dengan bahan tambah metakaolin

- $\mathrm{B}_{\mathrm{HSC}} \mathrm{N}$ : Beton tanpa bahn tambah

\section{KESIMPULAN}

Berdasarkan hasil pengujian dan analisis yang dilakukan, dapat diambil kesimpulan bahwa kuat desak beton dengan bahan tambah metakaolin $\left(\mathrm{B}_{\mathrm{HSC}} \mathrm{MK}\right.$ ) mendapatkan nilai kuat desak yang lebih tinggi daripada beton tanpa bahan tambah $\left(\mathrm{B}_{\mathrm{HSC}} \mathrm{N}\right)$. Persentase kenaikan kuat desak antara beton $\mathrm{B}_{\mathrm{HSC}} \mathrm{MK}$ terhadap $\mathrm{B}_{\mathrm{HSC}} \mathrm{N}$ adalah sebesar 16,27 \% pada umur 28 hari. Nilai volume pori (cc/g) beton dengan bahan tambah metakaolin ( $\mathrm{B}_{\mathrm{HSC}} \mathrm{MK}$ ) lebih kecil daripada beton tanpa bahan tambah $\left(\mathrm{B}_{\mathrm{HSC}} \mathrm{N}\right)$ dengan persentase penurunan 3,44 \% pada umur 7 hari; 3,57\% pada umur 14 hari; 8,33\% pada umur 21 hari dan 13,63\% pada umur 28 hari.

\section{UCAPAN TERIMA KASIH}

Terima kasih kepada Laboratorium Bahan dan Struktur Program Studi Teknik Sipil, Fakultas Teknik, Universitas Sebelas Maret yang telah menyediakan peralatan guna kelancaran penelitian ini.

\section{REFERENSI}

Badan Standarisasi Nasional. 2000. Tata Cara Perencanaan Campuran Tinggi dengan Semen Portland dengan Abu Terbang (SNI 03-6468-2000). Badan Standarisasi Nasional. Jakarta Pusat.

Badan Standarisasi Nasional. 2011. Cara Uji Kuat Tekan Beton dengan Benda Uji Silinder (SNI 1974-2011). Badan Standarisasi Nasional. Jakarta Pusat.

Badan Standarisasi Nasional. 2013. Persyaratan Beton Struktural untuk Bangunan Gedung (SNI 2847-2013). Badan Standarisasi Nasional. Jakarta Pusat.

Dharmawan, E.A. 2017. Kajian Pengaruh Variasi Komposisi Metakaolin Terhadap Parameter Beton Memadat Mandiri Dan Kuat Tekan Beton Mutu Tinggi. Universitas Sebelas Maret. Surakarta. Indonesia.

Departemen Pekerjaan Umum dan Tenaga Listrik. 1971. Peraturan Beton Bertulang Indonesia (PBI-1971). Bandung. Dipohusodo, Istimawan. 1999. Struktur Beton Bertulang. PT. Gramedia Pustaka Utama. Jakarta.

Kurtis, Kimberley. 2013. Structure of the Hydrated Cement Paste. Georgia Institute of Technology. Georgia.

Lathifah, P. 2018 . Kajian Modulus Elastisitas pada Beton Mutu Tinggi Memadat Mandiri dengan Variasi Penambahan Bahan Metakaolin. Universitas Sebelas Maret. Surakarta. Indonesia.

Mulyono, T. 2004. Teknologi Beton. Penerbit Andi Offset. Yogyakarta.

Paramita, Mondal. 2008. Nanomechanical Properties of Cementitious Materials. Disertasi pada Field of Civil and Enviromental Engineering Northwestern University. Illinois.

Srivastava, V., Kumar, R., Agarwal, V.C. 2012. Metakaolin Inclusion: Effect on Mechanical Properties of Concrete. Civil engineering department MNNIT. Allahabad. India. 